\title{
Integrasi Pengujian Peraturan Perundang-Undangan di Mahkamah Konstitusi sebagai Upaya Pembangunan Hukum Indonesia
}

\author{
Nafiatul Munawaroh dan Maryam Nur Hidayati \\ Mahaiswa Fakultas Hukum Universitas Islam Indonesia \\ Jln. Tamansiswa No. 158 Yogyakarta \\ nafimun@gmail.com
}

\begin{abstract}
The first and foremost problem in this study is testing the urgency of the legislation that is integrated in the Constitutional Court. Secondly, it deals with the relevance of the integration testing of the legislation to the development of law in Indonesia. This is a juridical normative research whose legal materials were analyzed descriptively and qualitatively. The study reveals that first, the idea of unification of judicial review of legislation in the Constitutional Court is very essential to do, in order to harmonize the legislation, to maximize the protection of constitutional rights of citizens, and to realize the supremacy of the constitution. Second, the unification of legislation testing can fix elements of the legal system that is particularly an instrument or substance of the law, which highly affect law-making and institutional capacity building, namely the Supreme Court, the Constitutional Court and the executive in Indonesia.
\end{abstract}

Key words: Constitutional, legislation testing, legal development.

\begin{abstract}
Abstrak
Pokok permasalahan dalam penelitian ini adalah, pertama, urgensi pengujian peraturan perundangundangan yang diintegrasikan di Mahkamah Konstitusi. Kedua, relevansi pengintegrasian pengujian peraturan perundang-undangan terhadap pembangunan hukum di Indonesia. Penelitian ini merupakan penelitian yuridis normatif, bahan-bahan hukum dianalisis secara deskriptif kualitatif. Hasil penelitian menyimpulkan pertama, gagasan penyatuan uji materi peraturan perundang-undangan di Mahkamah Konstitusi amat penting dilakukan, yaitu untuk melakukan harmonisasi antar peraturan perundangundangan, memaksimalkan perlindungan hak konstitusional warga negara dan mewujudkan supremasi konstitusi. Kedua, penyatuan pengujian peraturan perundang-undangan dapat memperbaiki elemen sistem hukum yaitu instrumen atau substansi hukumnya, yang akan berefek terhadap pembuatan hukum serta penguatan kelembagaan yaitu MA, MK dan eksekutif yang ada di Indonesia.
\end{abstract}

Kata kunci : Mahkamah konstitusi, pengujian peraturan perundang-undangan, pembangunan hukum 


\section{Pendahuluan}

Pasca perubahan konstitusi 1999-2002, pengaturan tentang perlindungan Hak Asasi Manusia warga negara semakin membaik, salah satunya adalah dengan adanya kewenangan uji materi peraturan perundang-undangan di Mahkamah Konstitusi (MK) dan Mahkamah Agung (MA). Akan tetapi, pengujian peraturan perundang-undangan di dua lembaga tersebut justru menimbulkan problematika tersendiri. Konstitusi Indonesia, UUD NRI 1945 Pasal 24A yang memberikan kewenangan kepada MA untuk menguji peraturan perundang-undangan di bawah undang-undang (UU) terhadap UU. Sedangkan Pasal 24C memberikan kewenangan kepada MK untuk menguji UU terhadap Undang-Undang Dasar (UUD). Tentu saja pengujian peraturan perudang-undangan di dua atap sebagaimana diatur di dalam dua pasal tersebut mempersulit proses harmonisasi dan sinkronisasi antar peraturan perundang-undangan. Hal ini menurut Jimly Ashshidiqie dapat menimbulkan perbedaan putusan atau bahkan putusan yang saling bertentangan antara MA dan $\mathrm{MK}^{1}$. Tidak hanya MA dan MK saja yang berwenang dalam melakukan pengujian peraturan perundang-undangan. Sebab, dalam praktiknya, pemerintah dapat melakukan pencabutan terhadap peraturan perundangperundangan sendiri, atau biasa disebut dengan executive review.

Awal mula terbentuknya MK, bertujuan untuk melindungi hak-hak konstitusional warga negara dan sebagai penjaga demokrasi, salah satunya adalah melalui kewenangannya menguji undang-undang yang merugikan atau berpotensi merugikan hak konstitusional masyarakat. Akan tetapi, ini kontradiktif dengan kondisi saat ini. Mahkamah Konstitusi yang dijuluki the guardian of constitution, tidak dapat maksimal dalam melindungi hak konstitusional warga negara dan menjaga konstitusi. Hal tersebut disebabkan pengujian peraturan perundang-undangan di bawah UU dilakukan di Mahkamah Agung, sedangkan MA tidak mempunyai kewenangan dalam menguji apakah suatu peraturan konstitusional atau tidak. Sedangkan yang berwenang menguji apakah sebuah peraturan konstitusional atau

${ }^{1}$ Ni'matul Huda, Pengujian Peraturan Perundang-undangan di Bawah Satu Atap Mabkamah Konstitusi dalam Dri Utari Christina dan Ismail Hasani (Ed), Masa Depan Mabkamah Konstitusi RI; Naskah Konferensi Mabkamab Konstitusi dan Pemajuan Hak Konstitusional Warga, , Setara Institute, Jakarta, 2013, hlm. 492 
tidak adalah MK, namun MK tidak berwenng melakukan tugas menguji peraturan perundang-undangan di bawah UU.

Potensi kerugian pengujian di dua atap ini terlihat dari beberapa kasus. Misal dalam pengujian Peraturan KPU No. 15 Tahun 2009 sebagaimana diubah dengan Peraturan KPU No. 26 Tahun 2009 tentang Pedoman Teknis Penetapan Dan Pengumuman Hasil Pemilihan Umum, Tatacara Penetapan Perolehan Kursi, Penetapan Calon Terpilih dan Penggantian Calon Terpilih dalam Pemilihan Umum Anggota Dewan Perwakilan Rakyat, Dewan Perwakilan Daerah, Dewan Perwakilan Rakyat Daerah Provinsi, dan Dewan Perwakilan Rakyat Daerah Kabupaten/Kota Tahun 2009 dan Peraturan KPU No. 259 Tahun 2009 tentang Penetapan Perolehan Kursi Partai Politik terhadap UU No. 10 Tahun 2008 tentang Pemilihan Umum Anggota Dewan Perwakilan Rakyat, Dewan Perwakilan Daerah, dan Dewan Perwakilan Rakyat Daerah, MA memutuskan pembentukan Peraturan KPU tersebut bertentangan dengan UU No. 10 Tahun 2008, sedangkan MK dalam pengujian Pasal 205 ayat (4) UU No. 10 Tahun 2008 adalah konstitusional bersyarat. ${ }^{2}$ Contoh lain yang menjadi permasalahan yang cukup pelik adalah mengenai Peraturan Daerah Syariah yang mulai menjamur di Indonesia. Sebagaimana dilansir oleh Kementrian Hukum dan HAM, setidaknya ada 92 buah Perda Syariah yang dipermasalahkan. ${ }^{3}$ Dari beberapa Perda syariah yang dipermasalahkan menurut Kemenkumham, salah satu contohnya adalah Perda Kota Tangerang No. 8 Tahun 2005 tentang Larangan Pelacuran. Perda Kota Tangerang No. 8 Tahun 2005 tentang Larangan Pelacuran yang telah di judicial review ke MA nyata-nyata diskriminatif dan telah melanggar hak-hak konstitusional warga negara, sebagai contoh adalah Lilis Mahmudah yang menjadi korban salah tangkap yang kemudian meninggal karena depresi, namun MA memutus perda tersebut sesuai dengan KUHP. ${ }^{4}$ Hal ini disebabkan MA tidak mempunyai wewenang untuk mengujikan perda tersebut dengan pasal HAM di

2 Ibid., hlm. 493.

http://ditjenpp.kemenkumham.go.id/perkembangan-harmonisasi-rpp-tahun-2010/50-kajian-daninventarisasi-perda/157-peraturan-daerah-yang-bernuansa-syariat-islam.html\#comment-2313 diakses pada hari Kamis tanggal 18 September 2014.

${ }^{4}$ Ismail Hasani, Integrasi Pengujian Peraturan Perundang-undangan dan Pemajuan Hak Konstitusional Warga Negara, dalam Dri Utari Christina dan Ismail Hasani (Ed), Masa Depan Mabkamah Konstitusi RI; Naskah Konferensi Mabkamah Konstitusi dan Pemajuan Hak. Konstitusional Warga, Setara Institute, Jakarta, 2013, hlm. 508-533. 
konstitusi. Begitu pula ketika sebuah perda dilakukan pengujian melalui executive review. Akibatnya, pengujian yang tidak terintegrasi di satu tempat, justru akan menimbulkan ketidakpastian hukum. Sehingga, upaya pembangunan hukum di Indonesia tidak akan berjalan secara maksimal.

Uraian di atas menunjukkan bahwa pengujian peraturan perundangundangan di dua atap menyebabkan ketidakpastian hukum, sebab potensi untuk konflik antar putusan dari dua lembaga tersebut lebih besar. Selain itu, pengujian di dua atap menyebabkan perlindungan terhadap hak konstitusional warga negara dalam rangka pembangunan hukum menjadi tidak maksimal.

\section{Rumusan Masalah}

Adapun permasalahan yang akan diteliti, pertama, apa urgensi pengujian peraturan perundang-undangan yang diintegrasikan di Mahkamah Konstitusi? Kedua, apa relevansi pengintegrasian pengujian peraturan perundang-undangan terhadap pembangunan hukum di Indonesia?

\section{Tujuan Penelitian}

Adapun tujuan penelitian ini untuk mengetahui, pertama, urgensi pengujian peraturan perundang-undangan yang diintegrasikan di Mahkamah Konstitusi. Kedua, relevansi pengintegrasian pengujian peraturan perundang-undangan terhadap pembangunan hukum di Indonesia.

\section{Metode Penelitian}

Jenis Penelitian ini adalah penelitian kualitatif dengan metode pendekatan yuridis normatif melalui kajian peraturan perundang-undangan dan literatur yang berhubungan dengan masalah. Jenis data yang digunakan adalah data sekunder yang terdiri atas bahan hukum primer yakni peraturan perundang-undangan, bahan hukum sekunder berupa buku-buku, dokumen, jurnal, data elektronik serta berbagai artikel yang mendukung penelitian ini. Bahan hukum tersier, berupa 
kamus dan ensiklopedia. Teknik pengolahan data akan dianalisis secara deskriptif kualitatif.

\section{Hasil Penelitian dan Pembahasan}

\section{Negara Hukum dan Hirarki Norma Hukum}

Konstitusi Indonesia menegaskan bahwa negara Indonesia berdasarkan atas hukum, hal ini termaktub dalam Pasal 1 ayat (3) UUD 1945. Salah satu prinsip yang menyangga tegaknya negara modern ini adalah supremasi hukum (Supremacy of Law). Letak supremasi hukum negara Indonesia adalah konstitusi. Dimana konstitusi materi muatannya mengandung jaminan terhadap hak-hak asasi manusia dan warga negaranya serta ditetapkannya susunan ketatanegaraan dan pembagian kekuasaan secara fundamental. ${ }^{5}$ Di samping itu, J.B.J.M. ten Berge menyebutkan bahwa salah satu prinsip negara hukum adalah adanya asas legalitas. Asas legalitas menghendaki bahwa undang-undang secara umum harus memberikan jaminan (terhadap warga negara) dari tindakan (pemerintah) yang sewenang-wenang, kolusi, dan berbagai jenis tindakan yang tidak benar. sehingga pelaksanaan wewenang oleh organ pemerintahan harus ditemukan dasarnya pada undang-undang tertulis. ${ }^{6}$ Mengingat pentingnya kedudukan peraturan perundang-undangan tersebut dalam sistem ketatanegaraan kita baik karena materi muatan maupun kedudukannya maka tertib peraturan perundangan wajib untuk diwujudkan, salah satunya melalui pengujian peraturan perundang-undangan.

Pengujian peraturan perundang-undangan erat kaitannya dengan hirarki peraturan perundang-undangan. Mengingat bahwa tata peraturan perundangundangan harus tersusun secara hierarkis dan saling berkaitan satu sama lain secara teoritik telah tersampaikan melalui teori Hans Kelsen mengenai Stufenbau des Recht atau hirarki norma hukum. Dalam teori ini berintikan bahwa kaidah hukum merupakan suatu susunan yang berjenjang dan setiap kaidah hukum yang

${ }^{5}$ J.G Steenberk, dalam Dahlan Thaib (et.al), Teori dan Hukum Konstitusi, Rajawali Grafindo, Jakarta, 2012, hlm. 15.

${ }^{6}$ J.B.G.M. ten Berge, Besturen door de Overbeid, W.E.J.Tjeenk Willink, Deventer, 1996, hlm 34-38 dalam Ridwan HR, Hukum Administrasi Negara, Raja Grafindo Persada, Jakarta, 2011, hlm. 9 
lebih rendah bersumber dari kaidah yang lebih tinggi. ${ }^{7}$ Hans Kelsen menjelaskan lebih lanjut bahwa, kaidah hukum itu sendiri tidak lain adalah "command of the sovereign"-kehendak yang berkuasa. ${ }^{8}$ Sehingga hukum itu adalah sah (valid) apabila dibuat oleh lembaga atas otoritas yang berwenang membentuknya dan berdasarkan norma yang lebih tinggi, dimana norma yang lebih rendah harus sesuai dengan yang lebih tinggi, dan norma yang lebih tinggi menjadi acuan norma di bawahnya. Hal ini senada seperti apa yang dikemukakan oleh Merkl bahwa suatu norma hukum itu selalu mempunyai dua wajah (das Doppelte Rechtsantkizt). ${ }^{9}$ Dalam hal tata susunan atau hirarki sistem norma-norma yang tertinggi (norma dasar) itu menjadi tempat bergantungnya norma-norma yang di bawahnya sehingga apabila norma dasar itu berubah, maka akan menjadi rusaknya sistem norma yang berada di bawahnya. Di Indonesia norma tertinggi ini dikontekskan dalam bentuk konstitusi. Karena itu, norma ini merupakan alasan tertinggi bagi keabsahan norma, norma yang satu diciptakan sesuai dengan yang lain, dan dengan demikian terbentuklah sebuah tatanan hukum dalam struktur hierarkis. ${ }^{10}$

Berdasarkan uraian tersebut, dapat disimpulkan Indonesia menganut teori yang dicetuskan Hans Kelsen, stufen bau das recht. Hal ini dibuktikan dengan UU No. 12 Tahun 2011 tentang Pembentukan Peraturan Perundang-undangan pada Pasal 7 disebutkan hierarki peraturan perundang-undangan di Indonesia saat ini adalah yang tertinggi UUD NRI 1945, Tap. MPR, Undang-undang/Peraturan Pemerintah Pengganti Undang-undang, Peraturan Pemerintah, Peraturan Presiden, Peraturan Daerah Provinsi dan Peraturan Daerah Kabupaten/Kota. Peraturan yang dikeluarkan oleh lembaga-lembaga negara seperti DPR, MA, MK, BPK dan lain-lain juga menjadi kewenangan MA dalam hal pengujian, selama peraturan tersebut dikeluarkan sesuai perintah peraturan perundang-undangan yang lebih tinggi. Pasal 24A UUD NRI 1945 diatur bahwa Mahkamah Agung mempunyai kewenangan untuk menguji peraturan perundang-undangan di bawah undang-undang terhadap undang-undang.

\section{1, hlm. 23}

${ }^{7}$ Ni'matul Huda dan R. Nazriyah, Teori dan Pengujian Peraturan Perundang-undangan, Nusamedia, Bandung,

${ }^{8}$ Ibid., hlm. 24

${ }^{9}$ Ibid., hlm. 23

${ }^{10}$ Hans Kelsen, Teori Hukum Murni, Nusa Media, Bandung, 2008, hlm. 244. 
Sedangkan untuk menguji UU terhadap UUD NRI 1945 diatur lebih lanjut di Pasal 24C yakni melalui Mahkamah Konstitusi.

Konsekuensi penting dari prinsip-prinsip di atas, harus diadakan mekanisme yang menjaga dan menjamin agar prinsip tersebut tidak disimpangi atau dilanggar. Mekanismenya yaitu ada sistem pengujian secara yudisial atas setiap peraturan perundang-undangan, atau kebijakan maupun tindakan pemerintahan lainnya, terhadap peraturan perundang-undangan yang lebih tinggi tingkatannya atau tingkat tertinggi yaitu UUD. ${ }^{11}$ Tanpa konsekuensi tersebut, tata urutan tidak akan berarti. Suatu peraturan perundang-undangan tingkat lebih rendah dapat tetap berlaku walaupun bertentangan dengan peraturan perundang-undangan tingkat lebih tinggi. ${ }^{12}$ Sehingga mekanisme penyatuan pengujian ini harus diterapkan, agar peraturan yang lebih tingga dapat sinkron dengan peraturan yang lebih rendah, serta dapat disesuaikan dengan konstitusi semua aturan hukum yang ada.

\section{Pengujian Peraturan Perundang-undangan Masa Kini dan Harapan Masa Depan}

Pengujian peraturan perundang-undangan atau judicial review merupakan sarana untuk menilai suatu peraturan perundang-undangan yang lebih tinggi secara hirarkis. ${ }^{13}$ Menurut Brewer Carrias, judicial review ini penting dilakukan sebagai upaya dari yudikatif untuk menjamin tindakan legislatif dan eksekutif sesuai dengan hukum tertinggi, yaitu konstitusi. ${ }^{14}$ Pengujian peraturan perundangundangan adalah sebuah konsekuensi logis dari teori Hans Kelsen tentang hirarki norma hukum di dalam sistem hukum yang menggunakan peraturan hukum tertulis sebagai sumber yang dominan. Hal ini merupakan cara untuk menjaga konsistensi antar peraturan yang ada. ${ }^{15}$

Perdebatan tentang kewenangan pengujian peraturan perundangundangan juga muncul dalam perubahan UUD 1945 periode 1999-2002. Pembahasan di Badan Pekerja Panitia Ad Hoc pada bab kekuasaan kehakiman, perdebatan pengujian peraturan perundang-undangan juga mengenai antara

\footnotetext{
${ }^{11}$ Ni'matul Huda dan Riri Nazriyah, Teori ..., Op. Cit., hlm. 34

${ }^{12}$ Ibid., hlm. 34

13 Ibid., hlm.131.

${ }^{14}$ Ibid., hlm. 127.

${ }^{15}$ Jimly Asshidiqie, Konstitusi \& Konstitusionalisme Indonesia, Sinar Grafika, Jakarta, 2011, hlm. 245.
} 
disatukan di MK atau kewenangan Mahkamah Konstitusi hanya khusus untuk UU terhadap UUD, sedangkan peraturan di bawah UU diuji di MA. Pihak yang sepakat pengujian peraturan perundang-undangan dipusatkan di Mahkamah Konstitusi salah satu alasan sebagaimana diungkapkan oleh Sutjipto dari F-UG, bahwa hak uji dimana-mana tersentralisasi di satu Mahkamah, tidak di dua mahkamah. ${ }^{16}$ Pernyataan ini memperkuat pernyataan Frans F.H. Matrutty bahwa hak uji materi ini haruslah menjadi kewenangan dari MK dengan tujuan agar aturan hukum diuji konstitusionalismenya atau sebagai wujud penjagaan constitutionality of law. ${ }^{17} \mathrm{Hal}$ ini senada dengan pendapat M. Yamin di dalam rapat panitia perancang UUD mengenai kewenangan Mahkamah Agung. Usulan Yamin dalam rapat tersebut adalah MA dalam melakukan kekuasaan kehakiman adalah membanding undang-undang supaya sesuai dengan hukum adat, hukum syariah dan UUD serta melakukan pembatalan undang-undang. ${ }^{18}$ Sehingga, dapat dilihat bahwa, gagasan pengujian peraturan perundang-undangan di satu tempat telah muncul sejak lama.

Pengujian peraturan perundang-undangan di bawah UU terhadap undangundang di MA, justru menimbulkan permasalahan tersendiri. Jika merujuk pada Peraturan MA No. 1 Tahun 2011 tentang Hak Uji Materiil, bahwa MA dalam memutus sebuah peraturan perundang-undangan yang sedang diujikan dinyatakan tidak sah atau tidak berlaku untuk umum, dan memerintahkan instansi yang bersangkutan untuk mencabutnya. Dari PERMA tersebut, tentu saja putusan MA ini berpotensi untuk menimbulkan konflik antara putusan MA dengan Pemerintah Daerah yang bersangkutan jika pencabutan tidak dilaksanakan. ${ }^{19}$ Sehingga, putusan MA dalam kewenangan uji materiil justru menjadikan proses penegakan hukum bertele-tele, sebab melibatkan lembaga eksekutif yang notabene bukan pihak yang berwenang dalam bidang yudisial untuk turut mencabut peraturan hukum yang dinyatakan tidak sah atau tidak berlaku umum.

${ }^{16}$ Mahkamah Konstitusi Republik Indonesia, Naskah Komprehensif Perubahan Undang-undang Dasar Republik Indonesia 194; Buku VI Kekuasaan Kehakiman, Sekretariat Jenderal dan Kepaniteraan Mahkamah Konstitusi, Jakarta, 2008, hlm. 359

${ }^{17}$ Ibid., hlm. 355

${ }_{18}$ Muhammad Yamin, Undang-Undang Dasar 1945 Djilid Pertama, Cet.II, 1971, hlm. 332

${ }^{19}$ Ni'matul Huda dan R. Nazriyah, Teori dan ..., Op. Cit., hlm. 143. 
Polemik lain dari pengujian peraturan perundang-undangan di dua atap terlihat dari Pasal 55 UU No. 24 Tahun 2003 jo UU No. 8 Tahun 2011 tentang Mahkamah Konstitusi pengujian peraturan perundang-undangan di bawah undangundang yang sedang dilakukan oleh Mahkamah Agung wajib dihentikan ketika undang-undang yang menjadi dasar pengujian peraturan tersebut sedang dalam proses pengujian Mahkamah Konstitusi sampai ada putusan MK. Pasal ini justru menjadikan kewenangan pengujian peraturan perundang-undangan menjadi tumpang tindih antara MK dan MA.

Kerancuan dan kesulitan untuk pengujian yang akan terjadi dengan kondisi pengujian dua atap saat ini dapat dibuktikan apabila suatu Perda, Peraturan gubernur/Bupati/Walikota yang ternyata bersinggungan dengan materi muatan HAM yang ada di konstitusi. Hal ini dikarenakan batu ujinya adalah UUD 1945. MA tidak memungkinkan untuk menguji perda-perda atau Peraturan Gubernur/ Bupati/Walikota tersebut karena batu ujinya UUD 1945, jika dipaksakan untuk mengujinya, MA hanya bisa menggunakan batu ujinya UU HAM. MK juga tidak memungkinkan untuk mengujinya meskipun materi muatan Perda atau Peraturan gubernur/Bupati/Walikota yang ternyata bersinggungan dengan materi muatan UUD 1945, karena posisi Perda atau Peraturan gubernur/Bupati/Walikota berada jauh di bawah undang-undang. ${ }^{20}$

Selain pengujian peraturan perundang-undangan di MA dan MK, ternyata peraturan perundang-undangan dapat diuji oleh pemerintah sendiri. Pasal 145 UU No. 32 Tahun 2004, Perda yang tidak bertentangan dengan peraturan perundangundangan yang lebih tinggi dan/atau kepentingan umum, maka dapat dilakukan executive review dimana Pemerintah melalui Peraturan Presiden dapat membatalkan Perda tersebut, tanpa melalui pengujian di MA. ${ }^{21}$ Sehingga, pengujian peraturan perundang-undangan di Indonesia saat ini menjadi cukup pelik, sebab dilakukan oleh tiga lembaga, yaitu MA, MK dan pemerintah. Oleh karena itu, diperlukan upaya untuk menyatukan pengujian tersebut di MK.

\footnotetext{
${ }^{20}$ Ni'matul Huda, Perkembangan Hukum Tata Negara: Perdebatan dan Gagasan Penyempurnaan, FH-UII Press, Yogyakarta, 2014, hlm. 6.

${ }^{21}$ Ibid., hlm. 489.
} 
Mahkamah Konstitusi sejak berdirinya ditujukan untuk melindungi konstitusi dan demokrasi. Melihat track record atau rekam jejak MK dalam kinerjananya, maka MK merupakan lembaga yang mampu menjaga konstitusi serta berkontribusi dalam pembangunan hukum di Indonesia. Sampai tahun 2014, perkara yang masuk ke MK sejumlah 956 permohonan, dengan putusan 552 buah, dengan jumlah permohonan yang dikabulkan sebanyak 282 buah. ${ }^{22}$ Dengan rekam jejak yang baik dan dipercaya masyarakat dalam pengujian peraturan perundangundangan, khususnya UU terhadap UUD, maka sudah selaiknya harapan untuk MK dapat menguji konstitusionalitas dari sebuah peraturan perundang-undangan dapat diwujudkan. Tentu saja hal ini bertujuan untuk perbaikan hukum Indonesia ke depan.

\section{Gagasan Perubahan Konstitusi: Integrasi Pengujian Peraturan Perundang- Undangan}

Pembangunan hukum menurut Afan Gaffar adalah ketika sebuah negara menciptakan sebuah hukum, pada dasarnya ia sedang melakukan pembangunan hukum yang mana tujuannya adalah untuk menjamin hak-hak dasar masyarakat dan melindungi kepentingan masyarakat. ${ }^{23}$ Pembangunan hukum di Indonesia haruslah dimulai melalui sistem hukum, yang terdiri atas kelembagaan (institusional), kaedah aturan (instrumental), dan perilaku subyek hukum yang menyandang hak dan kewajiban (elemen subyektif dan kultural). ${ }^{24}$ Hal ini senada dengan Lawrance M. Friedman, bahwa sistem hukum terdiri atas tiga elemen, yaitu substansi, struktur dan budaya hukum. ${ }^{25}$ Elemen sistem hukum tersebut mencakup kegiatan pembuatan hukum (law making), kegiatan pelaksanaan hukum (law administrating) dan peradilan atas pelanggaran hukum (law adjudicating atau law enforcement). ${ }^{26}$ Pengujian di dua Mahkamah justru menimbulkan kesulitan dalam proses law enforcement. Sebab, ketika sebuah peraturan perundang-

22 http://www.mahkamahkonstitusi.go.id/index.php?page=web.RekapPUU diakses pada hari Sabtu, tanggal 20 September 2014.

${ }^{23}$ Afan Gaffar, Pembangunan Hukum dan Demokrasi, dalam Moerdiono dkk, Politik Pembangunan Hukum Nasional, UII Press, Yogyakarta, 1992, hlm. 103-104

${ }^{24}$ Jimly Asshidiqie, Implikasi Perubahan UUD 1945 terbadap Pembangunan Hukum Nasional, 2005, Jakarta, MK RI, versi e book diunduh melalui jimly.com diakses pada hari Jumat tanggal 19 September 2014, hlm. 21.

${ }^{25}$ Muhammad Erwin, Filsafat Hukum: Refleksi Kritis terhadap Hukum, Rajawali Press, Jakarta, 2012, hlm. 107.

${ }^{26}$ Ibid. 
undangan bertentangan dengan konstitusi, namun peraturan tersebut tidak dicabut atau dibatalkan, maka akan mengganggu proses pembangunan hukum. Pembangunan hukum harus dilakukan melalui penataan hukum serta penegakan hukum yang dimulai dari hukum tertinggi yaitu konstitusi. ${ }^{27}$

Integrasi pengujian peraturan perundang-undangan di Mahkamah Konstitusi, hakikatnya dapat memperbaiki sistem hukum melalui instrumen atau substansi dan kelembagaan. Pertama, gagasan ini akan memperbaiki elemen sistem hukum berupa instrumen atau substansi. Dalam integrasi pengujian peraturan perundang-undangan, perbaikan instrumen dapat dilakukan melalui upaya harmonisasi antar peraturan perundang-undangan. Proses penataan antar peraturan perundang-undangan dapat terlaksana ketika MK melakukan pengujian antar peraturan perundang-undangan, yang disandarkan pada konstitusi. Mengingat perubahan konstitusi 1999-2002 tentunya terdapat beberapa substansi dari UUD yang ikut dirubah. Akan tetapi, sampai saat ini banyak produk legislasi yang masa berlakunya telah dimulai sebelum dilaksanakan perubahan konstitusi 1999-2002. Dalam hal ini, tentunya beberapa produk legislasi yang sudah ada sebelum perubahan konstitusi tidak mendasarkan maupun bersumber sepenuhnya terhadap perubahan konstitusi yang baru. Tidak hanya peraturan perundang-undangan yang ada sebelum perubahan UUD NRI 1945 pada periode 1999-2002, namun setiap peraturan perundang-undangan yang ada saat ini maupun kedepannya, haruslah mengacu pada konstitusi. Jika pengujian peraturan perundang-undangan tidak dipusatkan pada satu Mahkamah, yaitu Mahkamah Konstitusi, maka proses instrumen atau substansi hukum yang ada tidak akan mengacu pada konstitusi. Inilah ruang MK yang berfungsi sebagai pelindung konstitusi untuk mengupayakan harmonisasi aturan hukum dengan konstitusi. Hal ini bertujuan agar sejalan dengan prinsip supremasi konstitusi. Proses penegakan supremasi konstitusi, produk legislasi tidak boleh dibiarkan bertentangan dengan konstitusi, karena apabila hal ini tetap dibiarkan, maka akan terjadi proses deligitimasi konstitusi, pelanggaran hak konstitusional warga negara, bahkan dapat berujung pada ambruknya demokrasi.28 Substansi hukum yang sesuai dengan hukum dasar yaitu konsitusi, tentu saja akan

${ }^{27}$ Ni'matul Huda, Perkembangan Hukum Tata Negara..., Op. Cit., hlm. 7.

${ }^{28}$ Ibid. 
berpengaruh terhadap pembuatan hukum atau law making yang dilakukan oleh legislatif. Sehingga, sistem hukum yang semakin baik dalam rangka pembangunan hukum akan dapat terwujud.

Kedua, yakni dapat memperbaiki kelembagaan atau institusional yang kedepan akan berpengaruh pada penegakan hukum atau law enforcement. Sebab, tumpang tindih kekuasaan antara MA dan MK dalam pengujian peraturan perundang-undangan yang dicantumkan dalam Pasal 55 UU No. 24 Tahun 2003 jo UU No. 8 Tahun 2011 tentang Mahkamah Konstitusi sebagaimana dijelaskan dalam sub-bab sebelumnya, tentu saja dapat berimplikasi terhadap penguatan MK maupun MA. Mahkamah Konstitusi yang bertugas menjaga demokrasi, tentu saja perannya akan lebih kuat ketika diberikan kewenangan untuk menguji seluruh peraturan perundang-undangan. Sebab, menurut Jimly Asshidiqie, hakikatnya MK merupakan lembaga pengadilan hukum (court of law) dimana kegiatan judicial review semuanya diserahkan pada $\mathrm{MK}$, sedangkan MA, berkonsentrasi sebagai pengadilan keadilan (court of justice) yang fokus pada penanganan perkara yang diharapkan mewujudkan rasa adil masyarakat. ${ }^{29}$ Selain itu, hal ini juga menegaskan bahwa eksekutif atau pemerintah bukanlah berperan sebagai lembaga yudikatif sehingga dapat mengadili sebuah peraturan dan dapat mencabutnya sendiri. Tentunya, gagasan ini dapat menghindari penyalahgunaan kekuasaan oleh pihak eksekutif yang dapat mencabut peraturan yang dikeluarkan tanpa melalui lembaga yudikatif. Sehingga, dengan putusan MK No. 97/PUU-XI-2013 yang menyatakan pilkada tidak lagi menjadi wewenang MK, maka sudah selaiknya MK fokus menangani perkara yang terkait dengan pengujian konstitusionalitas dari peraturan perundang-undangan dalam rangka menjalankan fungsinya sebagai pelindung konstitusi dan demokrasi. Hal inilah yang dijadikan alasan peneliti bahwa gagasan ini akan memperkuat kelembagaan MK, MA dan pemerintah.

Oleh karena itu, diperlukan gagasan perubahan Undang-Undang Dasar 1945, untuk mengubah Pasal 24A dengan mengurangi kewenangan untuk menguji peraturan perundang-undangan di bawah undang-undang terhadap undang-undang dan menyempurnakan aturan Pasal 24C bahwa Mahkamah Konstitusi berwenang

${ }^{29}$ Ni'matul Huda, Hukum Tata Negara Indonesia, Rajawali Press, Jakarta, 2012, hlm. 215. 
menguji seluruh peraturan perundang-undangan di bawah konstitusi terhadap konstitusi.

\section{Penutup}

Gagasan penyatuan uji materi peraturan perundang-undangan di Mahkamah Konstitusi merupakan hal yang sangat penting dilakukan, untuk melakukan harmonisasi antar peraturan perundang-undangan serta mewujudkan supremasi konstitusi. Sebab, MK lah yang berwenang dalam menguji konstitusionalitasan dari sebuah aturan hukum.

Gagasan ini semata-mata adalah upaya membangun hukum di Indonesia melalui sistem hukum. Penyatuan pengujian peraturan perundang-undangan dapat memperbaiki elemen sistem hukum yaitu instrumen atau substansi hukumnya, yang akan berefek terhadap pembuatan hukum serta penguatan kelembagaan yaitu MA, MK dan eksekutif yang ada di Indonesia.

Uraian dalam penelitian ini kemudian mendorong peneliti untuk merekomendasikan kepada Majelis Permusyawaratan Rakyat untuk melakukan perubahan konstitusi, terutama pasal tentang kewenangan MA dan MK, untuk selanjutnya menambahkan kewenangan MK dengan pengujian seluruh peraturan perundang-undangan.

\section{Daftar Pustaka}

Asshidiqie, Jimly, Konstitusi \& Konstitusionalisme Indonesia, Sinar Grafika, Jakarta, 2011. Thaib, Dahlan (et.al.). Teori dan Hukum Konstitusi, PT Raja Grafindo Persada, Jakarta, 2012.

Christina, Dri Utari dan Ismail Hasani (Ed), Masa Depan Mahkamah Konstitusi RI; Naskah Konferensi Mahkamah Konstitusi dan Pemajuan Hak Konstitusional Warga, Setara Institute, Jakarta, 2013.

Erwin, Muhammad, Filsafat Hukum: Refleksi Kritis terhadap Hukum, Rajawali Press, Jakarta, 2012.

Kelsen, Hans, Teori Hukum Murni, Penerbit Nusa Media, Bandung, 2008. 
Mahkamah Konstitusi Republik Indonesia, Naskah Komprehensif Perubahan Undangundang Dasar Republik Indonesia 194; Buku VI Kekuasaan Kehakiman, Sekretariat Jenderal dan Kepaniteraan Mahkamah Konstitusi, Jakarta, 2008.

Moerdiono, dkk, Politik Pembangunan Hukum Nasional, Yogyakarta, UII Press, 1992.

Muhammad Yamin, Undang-Undang Dasar 1945, Djilid Pertama, Cet. II, 1971.

Ni'matul Huda dan R. Nazriyah, Teori dan Pengujian Peraturan Perundang-undangan, Nusa Media, Bandung, 2011.

Ni'matul Huda, Perkembangan Hukum Tata Negara: Perdebatan dan Gagasan Penyempurnaan, FH-UII Press, Yogyakarta, 2014. Hukum Ketatanegaraan Indonesia Ed. Revisi, Rajawali Grafindo, Jakarta, 2012. , Hukum Tata Negara Indonesia Ed. Revisi, Rajawali Grafindo: Jakarta, 2012.

Ridwan HR, Hukum Administrasi Negara, Raja Grafindo Persada, Jakarta, 2011.

\section{Peraturan Perundang-undangan}

Undang-Undang Dasar Negara Republik Indonesia 1945

UU No. 12 Tahun 2011 tentang Pembentukan Peraturan Perundang-undangan

UU No. 24 Tahun 2003 jo UU No. 8 Tahun 2011 tentang Mahkamah Konstitusi

UU No. 32 Tahun 2004 jo UU No. 12 Tahun 2008 tentang Pemerintahan Daerah

Peraturan Mahkamah Agung No. 1 Tahun 2011 tentang Uji Materiil

\section{Website}

Jimly Asshidiqie, Implikasi Perubahan UUD 1945 terhadap Pembangunan Hukum Nasional, 2005, Jakarta: MK RI, versi e book diakses melalui jimly.com

https://www.constituteproject.org/constitution/German_Federal_Republic_2012.pdf http:/ / ditjenpp.kemenkumham.go.id/perkembangan-harmonisasi-rpp-tahun2010/50-kajian-dan-inventarisasi-perda /157-peraturan-daerah-yangbernuansa-syariat-islam.html\# comment-2313

http:/ / www.mahkamahkonstitusi.go.id/index.php?page=web.RekapPUU 